\title{
Teaching Sustainability in Higher Education: Pedagogical Styles that Make a Difference
}

\author{
Carol Scarff Seatter \\ University of British Columbia \\ Kim Ceulemans \\ University of Victoria
}

\begin{abstract}
The challenge of teaching sustainable development in higher education can mean that students-as future citizens-are left without insight, commitment, or a sense of their position regarding meaningful beliefs and actions related to sustainability. A paradox arises when educators approach a sustainability curriculum that has the potential to transform students' thinking and actions, with a reductive and non-substantive pedagogy. This paper uses an epistemological and pedagogical analysis of relevant literature to redefine, clarify, and provide a more systematic and holistic understanding of a transformative pedagogy required for learning. The central thesis juxtaposes three sustainability curricular positions with three pedagogical models that vary decidedly in their emphasis on the prerogative of the learner's prior knowledge and beliefs, the engagement of the learner, and the potential for critical thinking and transformative learning. It is found that a transformative pedagogy overcomes and eliminates the paradox, helping societies become more sustainable.
\end{abstract}

\section{Résumé}

Parce que l'enseignement du développement durable représente un vrai défi pour les éducateurs, les étudiants sont privés de connaissance, d'engagement, et de compréhension de leur position à mieux connaître et à maîtriser tous les aspects du développement durable. Un paradoxe se pose lorsque les éducateurs abordent un programme d'études sur le développement durable avec le potentiel de transformer la pensée et les actions des étudiants avec une pédagogie réductrice. Une analyse épistémologique et pédagogique de la littérature a été utilisée pour redéfinir, clarifier et prévoir une compréhension 
plus systématique d'une pédagogie transformative nécessaire pour l'apprentissage du développement durable. La thèse centrale juxtapose trois positions curriculaires pour enseigner le développement durable avec trois modèles qui varient résolument dans leur accentuation sur l'apprenant et sa connaissance préalable, son engagement et son potentiel de la pensée critique et de l'apprentissage transformateur. L'article révèle que la pédagogie transformative surmonte et élimine le paradoxe, et ainsi aide la société à devenir plus durable.

\section{Introduction}

Higher education for sustainable development (HESD) is inspired by the aim to help students (i) develop sustainability attitudes, skills, and knowledge that inform decision making for the benefit of themselves and others, now and in the future, and (ii) act upon these decisions (UNESCO, 2009). Education for sustainable development, or the inclusion of key sustainability issues in all types of teaching and learning, has been supported and promoted over the last decades by global frameworks such as the United Nations' Decade of Education for Sustainable Development (2005-2014) and the Global Action Programme on Education for Sustainable Development (post-2014), both led by the United Nations Educational, Scientific and Cultural Organization (UNESCO) (Buckler \& Creech, 2014; UNESCO, 2014).

Higher education institutions can make a significant impact in the advancement of sustainable development as they take on various roles and responsibilities. Some of these include education for a sustainable society (James \& Card, 2012; Leal Filho, MacDermot, \& Padgam, 1996), developing future professionals as change agents (Moore, 2005; Svanström, Lozano-Garcia, \& Rowe, 2008), as well as facilitating the creation of spaces where ideas are expressed freely, paradigms are challenged, creativity is promoted, and new knowledge is acquired and generated (Barth, Godemann, Rieckmann, \& Stoltenberg, 2007; Cortese, 2003; Lozano, 2006).

Different kinds of models for teaching and learning are required to meet UNESCO's challenge; the very nature of sustainable development is much more complex than certain and is multidisciplinary at many levels (UNESCO, 2014). The goal of higher education is to support students in developing their capacity for recognizing and understanding the complexity of sustainability issues, and for thinking critically about assumptions, biases, beliefs, and attitudes while actively participating in their resolutions. The very nature of sustainability as a contested, multilayered and multifaceted subject provides rich opportunities for critical thinking and transformative learning (UNESCO, 2014).

Despite an urgent need for young people to gain vital knowledge and understanding of sustainability matters-and don the role of pro-sustainability citizens in thought and action-the nature of the pedagogy that neglects to tend to students' prior knowledge and lectures "a right position" is untenable, rendering it unsustainable in students' lives. A paradox exists between sustainability in higher education as a message that provokes thinking and action through transformative learning, and current sustainability in higher education pedagogy, which lacks the sustenance to facilitate sustainability thinking and behaviour, and often is stymied by a transmissive and lecture-driven delivery. Some issues to consider are: (i) whether there is a chasm between the transformative element in 
sustainability lifelong learning and the actuality; (ii) what there is to comprehend about models of teaching that could make a difference; and (iii) whether or not sustainability courses, as they are currently conceptualized and implemented, incite learning that matches initial goals.

In the present paper, definitions of approaches to sustainability (Alvarez \& Rogers, 2006), pinpointing their epistemological and pedagogical positions, are presented and discussed in light of HESD teaching and learning. The authors juxtapose approaches to sustainability with three basic teaching styles (Roberts \& Silva, 1968), three philosophical models that offer an in-depth critique of the necessary conditions for an effective teaching pedagogy in acquiring an understanding of, and engaging in, sustainability-related issues and solutions. The paper positions the concept of transformative learning as a reference point for effective HESD instruction and attempts to overcome the existing paradox of a powerful sustainability message delivered via a powerless pedagogy, which results in current teaching practices that lead to unsustainability.

\section{Literature Snapshot of Current Sustainability Challenges in Higher Education}

The current task facing HESD educators can be better understood through a glimpse at current practices and challenges revealed in the literature. The challenges are explored from the general to the more specific. The first challenge presents common misconceptions of sustainability concepts, while the second challenge reveals the tendency by many HESD instructors to infuse the curriculum with a particular agenda. The third challenge refers to three specific approaches to curriculum found throughout HESD. Together, these challenges underscore the need to articulate an HESD curriculum comprising transformative curriculum and pedagogy.

\section{Obstacles to Understanding Sustainability}

Education for sustainability is framed by radically different ways of understanding learning, which necessitates teachers who are prepared for transformative education with the accompanying personal transformation required (Wooltorton, 2002). In order to decipher students' comprehension of their learning about sustainability, Segalàs et al. (2010) found that students perceived sustainability as mainly related to technology and saw little relevance in social and attitudinal aspects. A second finding showed an increase in student knowledge about sustainable development from courses that apply a more community-oriented and constructive, active-learning pedagogical approach (Myers \& Beringer, 2010). In a more recent study, Segalàs et al. (2012) discovered a "mismatch" among the "experts" and students' understanding of sustainability. Students' complexity index was very low, revealing that either they perceive sustainability as unrelated to social and institutional aspects or they barely perceive sustainability as a complex issue. In calling for more systems and multidisciplinary thinking, with a greater societal focus, "the reorientation of the pedagogy and the learning processes is a must" (Segalàs, Mulder, \& Ferrer-Balas, 2012, p. 302).

In their attempt to overcome obstacles to understanding HESD, Lourdel, Martin, and Bererd (2006) pointed out numerous authors who have faced problems in establishing 
effective courses in HESD (e.g., Thomas, 2004; Velazquez, Munguia, Zavala, \& Esquer, 2002) and described a common feature of "denial" as a means of students distancing themselves from the problem. Sustainability is compared to a never-ending staircase with a series of steps in the right direction but with no prospect of reaching "the nirvana of complete sustainability" (Lourdel, Martin, \& Bererd, 2006). It is clear that the many misconceptions about the nature of sustainability and the limited feasibility of making a difference provoke a lack of optimism and motivation.

\section{Steering Practices}

The second challenge to effective HESD is the potential for imposing on students a particular agenda. In fact, many argue that the goal of current HESD is to steer students to locate themselves within the boundaries of a more or less preformed identity. One example is Hayes-Conroy and Vanderbeck's reference to the work of Morris (2002), whose goal, they have said, was for students to "journey to and [arrive] at a particularly essentialized conception of what ecological consciousness is" (Hayes-Conroy \& Vanderbeck, 2005, p. 313). From this perspective, HESD is viewed as work directed towards a particular end, an eco-centric worldview. Kowalewski (2002, p. 20) conceptualized his classroom as a space for learners to "change [their] consciousness of nature and [become] skeptical of technological and political fixes proposed by mainstream environmentalists." These findings are often found in the pedagogy of the environmental element of sustainability, a major component of sustainability studies. Hayes-Conroy and Vanderbeck (2005) spoke of the numerous scales utilized to determine where students stand in the sustainability debate and their scores that indicate where students should be locating themselves in relation to sustainability debates, and what sorts of actions should be considered consistent with a particular pro-sustainability position.

One prominent survey, utilized to assess university students' environmentally responsible behaviours, is labelled the New Ecological Paradigm (NEP) scale (Dunlap, Van Liere, Mertig, \& Jones, 2000). The three types of behaviour assessed are activism, consumerism, and recycling, and the Likert-type scale ranges from $\mathrm{U}(1)=$ usually to $\mathrm{R}(5)=$ rarely. A sample "activism behaviour" question is, "Are you enrolled in a course for the sole purpose of learning more about environmental issues?" One "consumerism behaviour" question is, "Have you purchased a product because it was packaged in reusable or recyclable containers?" Finally, one "recycling behaviour" question reads, "Have you sorted your trash to separate non-recyclable from recyclable material?" The 24-question NEP survey calculates students' sense of responsibility for the environment. Questions that on the survey appear only positive or at least harmless have the potential for steering students into taking the position expected of them. Students taking the NEP often felt there was a "general understanding" of what constitutes a pro-sustainability perspective but that a diversity of perspectives was not available to them (Hayes-Conroy \& Vanderbeck, 2005).

However, understanding and identifying with a particular worldview among several should be seen as indicative of the contestability and complexity of sustainability studies (Carew \& Mitchell, 2008) and an opportunity for the facilitation of critical thinking (Scarff Seatter, 2011). Rather than utilizing the complexity of sustainability subject matter to support student thinking, sustainability is being utilized as an opportunity to manoeuvre students into one viewpoint or another. 
Fundamental changes that include a broadening of democratic structures that engage people in formulating goals need to be an integral component of any class, course, or program (Rathzel \& Uzzell, 2009). For example, dominant forms of environmental education aim mainly to transmit information (Wals \& Jickling, 2002). As course titles change from "Environmental Education" to "Education for Sustainability" and "Education for Sustainable Development," there is no evidence that the pedagogical approach has altered. This is often the case even among some supporters of strong sustainability (Huckle, 2006). Thus, they reproduce within learning situations the existing relations of power, constituting learners as consumers instead of acknowledging them as active participants in a transformative process (Rathzel \& Uzzell, 2009, p. 271). Such studies provide evidence that higher education institutions attempt to shape sustainability subjects (Carew \& Mitchell, 2008; Cotton, 2006; Short, 2010) and raise student concerns regarding the shaping and steering occurring in sustainability classes (Hayes-Conroy \& Vanderbeck, 2005).

\section{Sustainability Curriculum: Three Positions}

Contrary to popular belief and practice at higher education institutions, curriculum is not limited to course content, although it is an essential component (Egan, 2012). When a curriculum position or emphasis is chosen, two key epistemological questions should be answered-first, "What is it that students should know and understand as a result of this course? That is, what content really matters?" and second, "How should it be taught?" (Case \& Daniels, 2002; Egan, 2012) These questions are important to consider because it follows that curriculum decisions of $w$ hat we teach determine how we teach (Orr \& Olson, 2007; Wiggins \& McTighe, 2005).

Alvarez and Rogers (2006) described three dominant emphases of HESD curriculum, synthesized from diverse approaches to teaching sustainability throughout the literature (see the Discussion section). These three basic curricular positions, although not comprehensive of all sustainability curricula in HESD, serve as a framework for examining various approaches to teaching and learning HESD that will be put forward for the readers' consideration in the following section of this paper. Alvarez and Rogers (2006) allowed readers a glimpse of the content component of curriculum; it is the authors' opinion that the content of the curriculum determines to a large extent the pedagogical component of the curriculum (Wiggins \& McTighe, 2005).

The first curriculum emphasis focuses on definitions of sustainability-"where they have emerged from, what they attempt to achieve and how they can be compared" (Baker, 1997, cited in Alvarez \& Rogers, 2006). Many courses are designed with such an emphasis, which supports an insubstantial and reductionist curriculum.

The second curriculum emphasis focuses on implementation, establishing what is unsustainable, how to make practices more sustainable, and how to evaluate sustainable outcomes. This modus operandi is prescriptive: environmental targets, audits, energy efficiency, and water efficiency, which involve "checklists, indicators, triple bottom-line accounting and ecological footprints" (Alvarez \& Rogers, 2006; Wackernagel \& Rees, 1996). When HESD courses are designed to emphasize implementation and result from a numeric prescriptive perspective alone, the result is similar to the first curriculum emphasis, supporting an insubstantial and reductionist curriculum. 
The third curriculum emphasis focuses on sustainability as discourse, a way of both defining and controlling an agenda for change and development worldwide (Darier, 1996; Luke, 1999; Sandilands, 1999, cited in Alvarez \& Rogers, 2006). Such work has to do with sustainability understood as a contested "on the ground" discourse utilized by competing individuals, groups, and cultures, with an emphasis placed on the complexity conceptions of sustainability. The concept of discourse, with origins in the process of experience and reasoning, includes written or spoken communication or debate that demands engaging in conversation and has implications of more than one viewpoint under study (Oxford University Press, 2009). When an HESD course emphasizes open-ended discourse, communication, and reasoning, the curriculum opens up to be more inclusive, interactive, and substantial.

In conclusion, the challenges to HESD described above are related to questionable pedagogical decision making. First, students view sustainability and associated issues as simple and straightforward, with a "right answer" mindset. As such, sustainability is perceived as unrelated to attitudes, community, and society. The second challenge relates to the diminution of the complexity and scope of HESD and the lack of engagement of the students' voices in an undemocratic classroom setting. The third challenge indicates that two of the three different conceptions of HESD curriculum are, for the most part, insubstantial and reductionist.

\section{Literature Snapshot of Sustainability Pedagogical Approaches}

Although still often applied in all types of education, it is known that traditional lecturing-or the passive reception of information by students-leads to low yields in information retention and to decreased student attention over the course of the lecture (Bonwell \& Eison, 1991; Felder, Felder, \& Dietz, 1998; Tinto, 1997). Traditional lectures are also not perceived as a place where learners can interact with ideas in a meaningful fashion (Laurillard, 2002, cited in Tormey, Liddy, Maguire, \& McCloat, 2008; Prosser \& Trigwell, 1999; Sullivan \& McIntosh, 1996).

As opposed to the passive reception of information via traditional lecturing, studentactivating teaching methods are pedagogical approaches that challenge students to participate actively, think critically, and reflect (Bonwell \& Eison, 1991; Hoogeveen \& Winkels, 1996). These types of alternative pedagogical approaches to traditional lectures are not new, but they are currently not widely utilized in higher education (Juarez-Najera, Dieleman, \& Turpin-Marion, 2006). The use of a particular methodology is highly dependent on the target (pedagogical and educational goals) and situational specifics (regarding students, teachers, and the learning environment) in which they will be used (De Freitas \& Oliver, 2006).

Given the diversity of students within a program, variation in the pedagogical methods is desirable (Bonwell \& Eison, 1991; UNESCO, 2006, 2012). Moreover, the variety of methods helps students to employ and develop different learning processes, making them grow as learners, and enhancing their skills and capacities to learn and think (UNESCO, 2012). Lecturers also take up another role when using alternative pedagogies: instead of the traditional "teaching," their role is often to "facilitate" or to set the stage for learning (Schelfhout et al., 2006; Singer \& Moscovici, 2008). 


\section{Constructivist Learning Approaches}

Constructivist learning theory contrasts with more traditional learning theories through its emphasis on the importance of the active involvement of learners in constructing knowledge for themselves, and on building new ideas or concepts based upon current knowledge and past experiences (Nie \& Lau, 2010; Tenenbaum, Naidu, Jegede, \& Austin, 2001; Tynjälä, 1999). Within the constructivist approach, learning is a learner's active, continuous process of individually and socially constructing and reconstructing meaning, while the teacher or lecturer acts as a facilitator who encourages students to discover principles for themselves and to construct knowledge by working to solve realistic problems (Ozkal, Tekkaya, Cakiroglu, \& Sungur, 2009). Constructivist teaching is initiated through the elicitation of ideas, recognizing that students have prior knowledge, ideas and theories, inviting students into the conversation, and encouraging them to interact with others (Scarff Seatter, 1998, 2003).

Thinking critically is at the heart of constructivist learning (Taylor, Fraser, \& Fisher, 1997), recognizing that old ways of understanding no longer connect with the present world (or the new topic being considered) and constructing new knowledge from connections between what once seemed to be the case and what is currently being presented in class. As a result, student active participation is key when thinking critically, and learning through lectures or textbooks rarely occurs. Case and Daniels's (2002) critical challenges, presented in Table 1 , are a set of pedagogical approaches, specifically addressing ways to problematize curriculum and assessment to ensure that critically thoughtful learning occurs. The critical challenges briefly addressed below are opportunities for constructivism in action. Three examples of "constructivist critical challenges," with a sustainability theme, have been added by the authors.

Another example of a present-day strategy used for constructivist learning and stimulating critical thinking is the inquiry approach. This approach refers to "instructional practices designed to promote the development of high order intellectual and academic skills through student-driven and instructor-guided investigations of student generated questions" (Justice, Rice, Roy, Hudspith, \& Jenkins, 2009, p. 843). The approach can be given to students in the form of either "guided inquiry," whereby the teacher picks the challenge and students offer possible solutions, then test them, or "open inquiry," with the teacher encouraging students to decide on a problem and an approach to solving it. This inquiry approach is often used due to its problematizing structure, which requires students to think, reflect, and make judgments in order to research effectively and offer solutions.

\section{Teaching Methods for Sustainability in Higher Education}

Certain authors within the HESD literature have related constructivist learning to learning about sustainability (e.g., Carew \& Mitchell, 2008; Ferreira, Lopes, \& Morais, 2006; Segalàs, Ferrer-Balas, \& Mulder, 2010). Learning about sustainability in a constructivist way involves adopting new ideas about the topic, but also modifying or abandoning existing ones. It also makes it necessary for students to consider their ideas regarding sustainability in order to develop them further, and for instructors or lecturers to elicit these ideas in order to take them into account when teaching. 
Table 1. Six Types of Critical Challenges and Examples* (adapted from Case \& Daniels, 2002)

Critique the Piece: Students assess the merits/shortcomings of a person, product, or performance (which may be teacher-provided or student-produced).

* Sustainability challenge: Critique the position that alternative energy sources, such as solar panels, are pseudo-sustainable solutions as they provide energy to run flat-screen TVs and air conditioners.

Rework the Piece: Students transform a product or performance in light of additional information or an assigned focus, perspective, genre, etc.

Decode the Puzzle: Students suggest and justify a proposed solution, explanation, or interpretation to a confusing or enigmatic situation.

Judge Better or Best: Students judge, from among two or more options (teacher-provided or student-generated), which best meets the identified criteria.

* "Grand Challenges Canada" (Grand Challenges Canada, 2016) challenges citizens to define a specific critical barrier that, if removed, would help solve an important health problem in the developing world, with a high likelihood of global impact through widespread implementation.

Which of the three challenges on the website-"saving lives at birth," "saving brains," or "hypertension in low- and middle-income countries"-would have the most global impact?

Design to Specs: Students develop a product that meets a given set of criteria/conditions.

* "My Sustainable Canada" (My Sustainable Canada, 2016) encourages Canadian snow resorts to improve "on-hill" operations.

Design a ski-hill operation with the best energy use for snowmaking, lifts, and lighting. Use the following criteria for judgment: (i) reduce energy use in snowmaking operations; (ii) use cleaner energy in snowmaking operations where possible; (iii) reduce energy use in lift operations; (iv) use cleaner energy in lift operations where possible.

Perform to Specs: Students perform or undertake a course of action that meets a given set of criteria/conditions.

The field of HESD also specifically stresses the need for alternative, student-centred methods for teaching and learning (Fortuin \& Bush, 2010; Sprain \& Timpson, 2012; Steiner \& Posch, 2006; UNESCO, 2012). Steiner and Posch (2006, p. 879) stated that "in teaching this concept [of sustainable development], existing conventional structures and processes need to be broken through. Different subjects and disciplines need to be integrated and university classes need to be connected to real-world problems and actors." This requires applying the principles of interdisciplinarity, trans-disciplinarity, and self- 
regulated learning, for which case studies can be a good starting point (Steiner \& Posch, 2006). Some student-activating pedagogies useful to address sustainability challenges in the classroom are, for example, different types of case studies (e.g., illustrated cases, dialog cases, data cases [see Sprain \& Timpson, 2012]) or teaching methods such as the ones presented by Ceulemans and De Prins (2010) (e.g., brainstorming, forms of dialogue, teamwork, problem-oriented education).

\section{Transformative Learning: Key Elements in the Literature}

The concept of transformative learning matters deeply when devising effective HESD and therefore plays a key role in the dissection and investigation of three pedagogical models and the accompanying curricular positions on sustainability (see the Discussion section below). The concept of transformative learning is utilized as a point of reference for individual/personal change, in this case change of one's position on "how best to be sustainable."

\section{Transformative Learning}

Traditional education is enacted through transferring knowledge from the one who knows to those who do not. Herein lies the tabula rasa or empty vessel learning theory, wherein the student is filled up with the instructor's knowledge, in contrast to constructivist learning theory. This approach does not prepare learners for change; rather, it prepares them for acceptance of the status quo and discourages reflection and questioning (Shor, 1993). A transformative pedagogy demands asking critical questions, continually searching for new sources and ideas (Åke Bjørke, 2014). Mezirow (1997) highlighted understanding the meaning of our experiences as the defining condition of being human. Often any "uncritically assimilated explanation" by "experts" will suffice, while in today's world of sustainability issues and challenges it is essential to make our own interpretations, rather than act on the "purposes, beliefs, judgments, and feelings of others." In this way, transformative learning develops autonomous thinking while transformative learning theory states that it does this through "effecting change in a frame of reference" (Cranton, 1994; Mezirow, 1990, 1997). For example, it is the transformative learners who move toward a frame of reference that is more inclusive, discriminating, self-reflective, and integrative of experience.

It is interesting to note here that Lozano (2014) put forward an argument for creativity and organizational learning as a means to support sustainability in higher education institutions. His characterization of creativity overlaps decidedly with that of transformative learning. In his work, Lozano describes creativity as an action that produces something novel and appropriate, which involves meme transfer throughout organizations and society. He defines this transfer or metanoia as a shift in mindset (one could relate this to critical thinking and a new frame of reference) or lifestyle (one could call this creative thinking, as it involves a change in behaviour). Mezirow's notion of a new frame of reference is similar to Lozano's (2014) model of students managing various mental modelsparadigms or perspectives-"by passing through a temporal process to expose assumptions, examining their consistency and accuracy, and seeing how different models can be brought together" (Lozano, 2014, p. 209). This critical bringing together of different models overlaps with the complexity of sustainability learning, which includes creative, critical, and transformational thinking and learning. 
Transformative learning is a process that (i) allows students to question taken for granted frames of reference to become more discriminating, open, and reflective (Greene, 2001), (ii) produces major changes in thinking, feeling, acting, relating, and being (Bennetts, 2003), and (iii) allows for evaluating values and assumptions for their effectiveness towards shared goals (Bhaskar, 2009). The conception of transformative learning appears in the literature as the "mechanism" and "process" for change at all levels of education (Greene, 1973; Sterling, 2001). The HESD literature depicts transformative learning as an outcome, goal, or result. It is described as the "competence" to understand multiple ways of looking at the world (Svanström, Lozano-Garcia \& Rowe, 2008; Wals \& Blaze Corcoran, 2006), and an "ultimate goal" that integrates action into one's new view of the world (Hauenstein, 1998; Sipos, Battisti, \& Grimm, 2008). This leads to an operational view of transformative learning, as a shift and subsequent action. In a discussion focusing on transformative learning and HESD, the authors acknowledge the essential skills of reflecting on personal beliefs, opening up to and having the competence to consider and understand the range of perspectives of others, and moving towards a new frame of reference as a position of greater inclusivity and awareness.

The nature of sustainability-a contested concept featuring an internal conflict due to its inherent trans-disciplinarity (Carew \& Mitchell, 2008; Moore, 2005)-demands the facilitation of critically thoughtful judgments and actions. An understanding of sustainability is rife with an internal clash among the three components: people (society), planet (environment), and profit (economics) (Carew \& Mitchell, 2008). A healthy, just, and sustainable future cannot be found by unthinkingly and uncritically continuing along the same tracks (Mogensen, 1997; Wals \& Jickling, 2002). Therefore, sustainability courses and classes are the prime opportunity for this kind of thinking for oneself.

Within the context of HESD literature are found concrete sustainability challenges, critical introspection, and subsequent transformative learning. Orr (1992) indicated that a paradigm change involves seeing the unfamiliar in the familiar, Hanson (1958) portrayed seeing as more than meets the eyeball, while Sterling (2001) postulated a third transformative level of learning, which affects participation, sense of belonging, and meaning negotiation. If transformative learning occurs, there is a change in beliefs and action, and that transformation is evident, especially to the learner. The evidence is an increased awareness of bias and assumptions, which accompanies a reassessment of one's position, beliefs, and understandings and offers a clearer, more authentic view of the sustainability challenge. Sipos, Battisti, and Grimm (2008) have spoken of an approach to achieving transformative learning in sustainability through uniting pedagogies that inform both sustainability and transformative education. Subsequently, the authors acknowledged and appreciated methodologies such as community service-learning, critical emancipatory pedagogy, and problem-based learning, whereby higher education institutions can enact both personal and societal transformations towards sustainability (Levkoe, Brail, \& Daniere, 2014).

\section{Philosophical Models and Styles of Teaching}

The challenges to HESD teaching can be framed via three teaching styles as part of a continuum from teacher-directed to extreme student-centered pedagogy (Roberts, 1996; Roberts \& Silva, 1968). Within this work are located the epistemological and pedagogical underpinnings of three basic approaches to teaching that can be effectively applied to instruction for HESD: the trialogue style, the imposition style, and the abandonment style. 


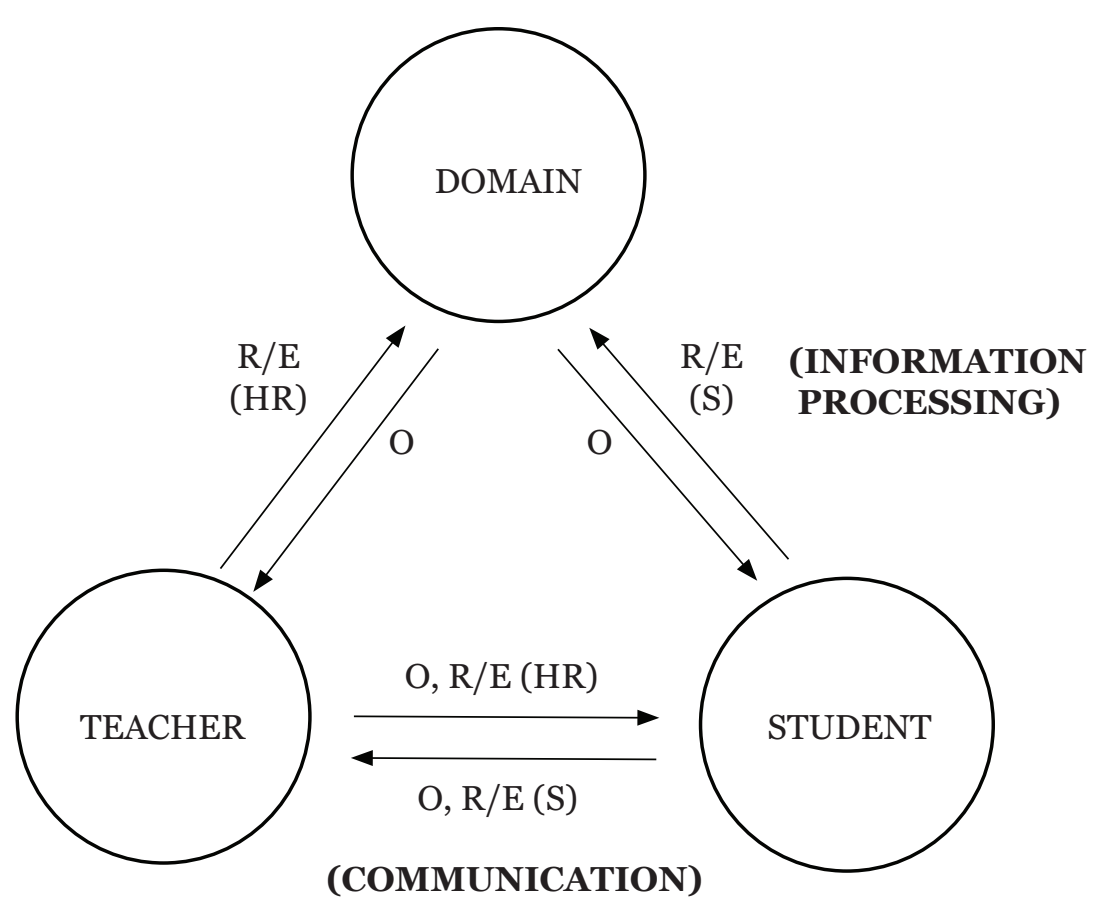

Figure 1. The "trialogue" style (source: Roberts, 1996; Roberts \& Silva, 1968). Code: $\mathrm{O}=$ observation(s); $\mathrm{R} / \mathrm{E}$ = representation and/or explanation; $\mathrm{S}=$ by the student; $\mathrm{HR}=$ by (others of) the human race.

Trialogue-style teaching is represented in Figure 1 by a triangular arrangement that suggests a three-way dialogue among teacher, student, and the domain of knowledge that is under investigation in the classroom. The students, as well as the instructor, have access to the domain of knowledge and bring to the investigation under study some constructed representations and explanations of their own (see "R/E" in Figure 1). Students' individually constructed ideas comprise their "prior knowledge," which forms the basis for the constructivist learning theory presented above. On both epistemological and ethical grounds, "[t]he existence of a student's prior conceptions is acknowledged, and their legitimacy at the student's level of understanding is taken as given" (Roberts, 1996, p. 422). Roberts and Silva (1968) portray the trialogue teacher as a coach or facilitator who is obliged to share with students the reasons for the differences between their own ideas ("R/E") and the portion of their intellectual heritage under study (see "O, R/E (HR)" in Figure 1). Communication between the domain and students, depicted by duo-directional arrows, illustrates this continual process of sense making and information processing between the domain and the students' world of knowledge, beliefs, and experiences. The students in turn contribute and test their ideas during classroom discussion.

Not all topics need to be treated using the trialogue style, but students should be able to critique their prior knowledge and assumptions and develop their understanding further through classroom discussions. What is important here is that communication by the teacher must be organized into the existing experience of the learner, otherwise it becomes nothing but mere words (Roberts \& Silva, 1968, p. 423). 
Two powerful examples of trialogue pedagogy and constructivist learning are described briefly here. The first example is an elective course that explores the complexity of "on the ground" sustainability in rural Australia, exposing students to conversations with ordinary people-for example, a family that specializes in growing tomatoes as a business-who are making sense of and negotiating change in their lives. In this learning experience, sustainability becomes a "complex set of discourses and practices that interweave through and over people's lives" rather than a checklist of appropriate practices (Alvarez \& Rogers, 2006, p. 183). The second example is of a group of teacher candidates in their final months of study to be secondary school science teachers. In the sustainability segment of the course, students were offered several field experiences in order to challenge their unexamined assumptions about what is and is not sustainable. One example was a visit to a local car-share cooperative and its various sites for car parking throughout the city. Student discourse with the owner of the business was intense, dynamic, and interactive around such issues as the amount of space in cities dedicated to transportation due to the high volume of vehicles, and many more topics. New knowledge clashed with old beliefs about car sharing, pollution levels, and spatial limitations (Scarff Seatter, notes on file, 2015).

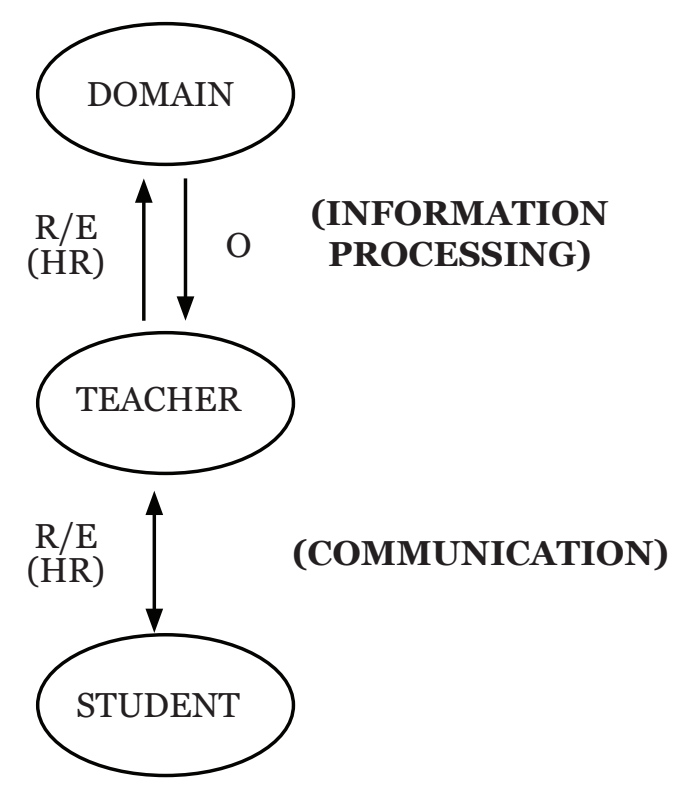

Figure 2. The "imposition" style (source: Roberts, 1996; Roberts \& Silva, 1968).

Code: $\mathrm{O}=$ observation(s); $\mathrm{R} / \mathrm{E}$ = representation and/or explanation; $\mathrm{S}=$ by the student; $\mathrm{HR}=$ by (others of) the human race.

The imposition style of teaching is represented in Figure 2 by a unilinear figure, wherein students are denied the chance to exercise their prerogative to contribute their own ideas or compare them with those in the greater domain of knowledge. The label "imposition" emphasizes the point that "the student's intellectual position is being 'imposed" (Roberts, 1996, p. 424). The instructor holds the final answers and maintains access to the domain of knowledge and understanding of the topic under study, essentially informing the student about what is meaningful and what is not. Within this model, students are allowed the opportunity for discussion, but it is essentially the teacher's agenda that 
defines the dialogue; it is left up to the students to determine how their ideas connect with the domain of knowledge under study, which allows the student to make the material meaningful. Roberts (1996) suggests that students require a metacognitive ability to follow through on why what is being learned is a better way-or not-to deal with the domain than their own way. As imposition implies the imposing of one's beliefs on another's, this style of pedagogy seldom varies from didactic lecturing, as input from the learner does not add to the learning but rather detracts from what "needs" to be said.

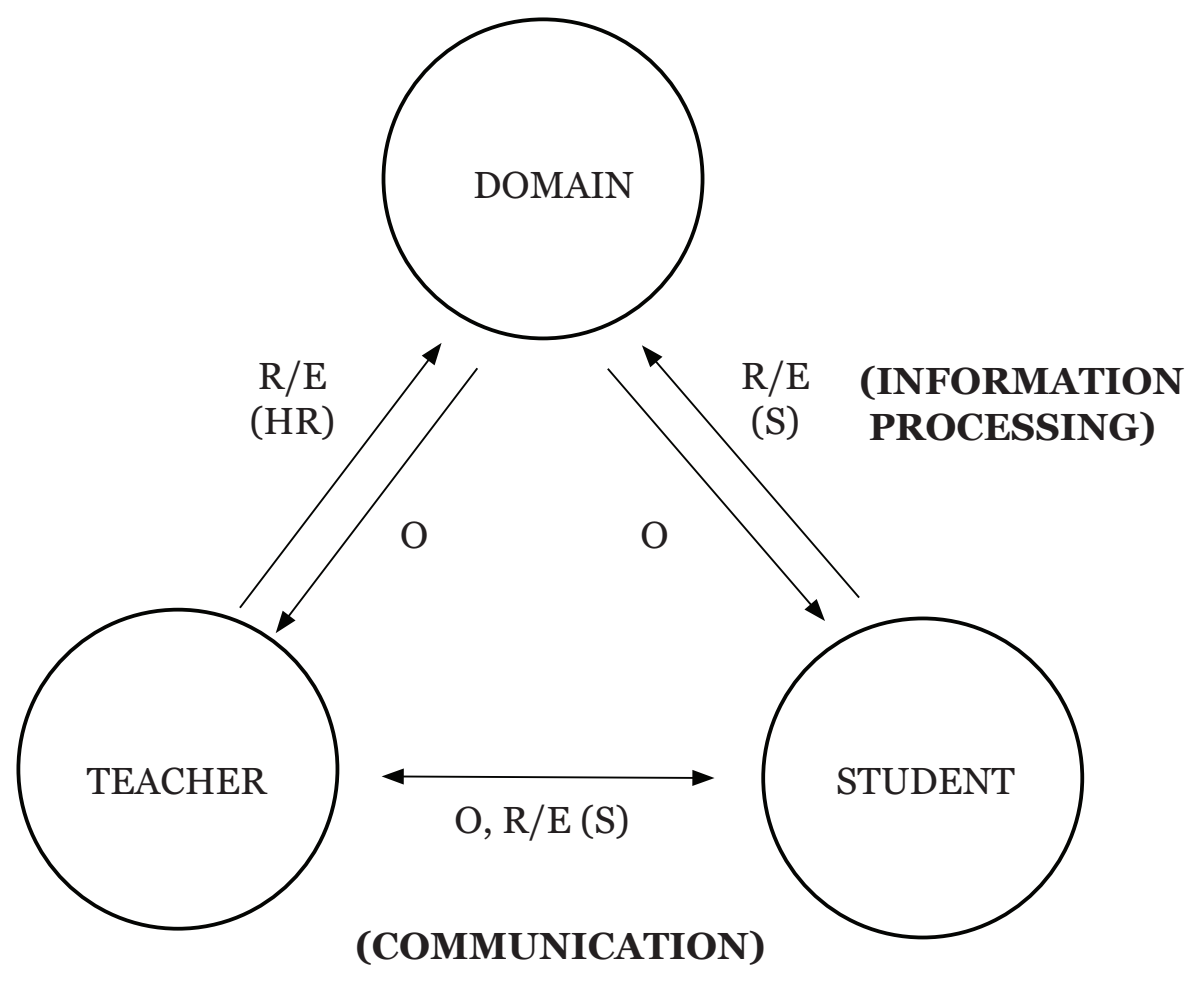

Figure 3. The "abandonment" style (source: Roberts, 1996; Roberts \& Silva, 1968). Code: $\mathrm{O}=$ observation(s); $\mathrm{R} / \mathrm{E}$ = representation and/or explanation; $\mathrm{S}=$ by the student; $\mathrm{HR}=$ by (others of) the human race.

The abandonment style of teaching is also represented in a three-way triangular figure (Figure 3), suggesting a three-way dialogue among teacher, student, and the domain of knowledge. The label is intended to suggest that students are effectively abandoned to their own devices and ideas. The single double-headed communication arrow indicates that there is much discussion between teacher and students, but it is limited to the students' questions and ideas. In such a teaching style, "the teacher's prerogative and responsibility to stand for and coach students about the reason behind the acceptance of particular explanations are insufficiently recognized" (Roberts, 1996, p. 425). Abandonment overemphasizes the student's prerogative, and "student sense making, of whatever quality, is accepted as the objective of the teaching" (Roberts, 1996, p. 425). This model of teaching is not prevalent in HESD but is included here for purposes of comparison. 


\section{Discussion}

Thus far we have presented and discussed the three most common curriculum positions found in sustainability courses in higher education, and we have coupled each with the most frequently accompanying pedagogical model (see Table 2). For the purpose of this paper, each of the three discrete sections depicts a distinct and probable pedagogical and epistemological stance. The three units are "Discourse Sustainability as Trialogue," "Implementation Sustainability as Imposition," and "Definitional Sustainability as Imposition."

Three of the approaches to sustainability (Alvarez \& Rogers, 2006) are viewed through the lenses of the three teaching styles of Roberts and Silva (1968). As a tool to consider and analyze some of the current practices of teaching in HESD, this chart serves as a useful starting point for future program design, implementation, and teaching in sustainability courses.

\section{Table 2. Sustainability Curriculum and Pedagogy Table for Higher Education}

\begin{tabular}{ll}
\hline Authors Juxtapose Three Approaches to & Three Basic Teaching Styles \\
Sustainability (Alvarez \& Rogers, 2006, p. & $\begin{array}{l}\text { (Roberts, 1996) with Accompanying } \\
\text { Appropriate Pedagogical Opportuni- } \\
\text { 177) }\end{array}$ \\
& ties (developed by authors)
\end{tabular}

Emphasis on sustainability as a discourse - a contested discourse that is spoken and claimed by competing groups and cultures, rather than a concept that can be pinned down and identified in the real world.
Trialogue teaching style

- Constructivist learning

- Inquiry methodology

- Authentic "field" excursions

- Case study

- Community service learning

- Active learning

Critical thinking, creativity, and transformative learning are fostered.

Imposition teaching style

- Lecture

- “As if" situation problem solving

Little critical thinking, creativity, or transformative learning are fostered.

Emphasis on definitions of sustainability where they have emerged from, what they attempt to achieve, and how they can be compared.
Imposition teaching style

- Lecture

- Traditional lab exercises

- Question and answer

- Assessment: exam and/or essay

Neither critical thinking, creativity, nor transformative learning are fostered. 


\section{The Sustainability Curriculum and Pedagogy Table for Higher Education}

The juxtaposition of the three curriculum emphases in sustainability courses-synthesized into three from numerous models in the work of Alvarez and Rogers (2006)-with the three teaching models presented in the writings of Roberts and Silva (1968) and Roberts (1996) offers a lens through which to conceptualize the influence of curriculum on teaching and, subsequently, the effect of teaching on transformative learning.

Sustainability as discourse and trialogue teaching. The trialogue teaching style is the only model that supports a pedagogical emphasis on sustainability as discourse. The students' prior knowledge and current ideas are integral to teaching and learning in this model; students become active participants within the classroom or during "on the ground" field experiences. In-depth engagement among learner, teacher, other learners, and the field of study - to the level at which the student is making a judgment about what is simply opinion and what to believe-is inherent within constructivist learning theory. Here, prior conceptions and beliefs are contrasted and compared with current knowledge under study, and new understandings are constructed (Phillips, 1995).

Justified belief results from bringing one's ideas to the table, listening to and considering the viewpoints of peers, as well as compiling knowledge previously acquired on the topic. In today's world, HESD is caught in a high-pressured polemic that demands students (and professors) take an informed and thoughtful stand of their own (Scarff Seatter, 2011) in order to avoid blindly accepting "any of many" diverse, contested positions. Students' ideas-prior ideas and in-class, developing ideas-as the core components of the curriculum serve as classroom catalysts for individual introspection and evaluation of assumptions, beliefs, and attitudes that influence decision making.

Sustainability implementation and imposition teaching. The implementation emphasis is described as the most reductive of the three emphases, as it is a reaction against "endless discussions over meanings and definitions," coupled with a plea to "get on with the task" (Alvarez \& Rogers, 2006, p. 177). "Getting down to business" refers to mathematically determining: "What practices are unsustainable," "How such practices are made more sustainable," and "How outcomes are best evaluated" (Wackernagel \& Rees, 1996). As described above, such courses consist of a series of "lists, indicators, triple bottom-line accounting and ecological footprints." The very premise of this managerial approach is that once we get enough of the "right kind of knowledge," sustainability will happen (Alvarez \& Rogers, 2006, p. 177). The most efficient method of gaining sufficient knowledge "of the right kind" is to maximize knowledge delivery during class periods. There can be an active role for higher education students in this pedagogical stance, as course objectives demand calculations of prescribed sets of data.

The pedagogical approach that best facilitates this kind of curriculum is the imposition style. The student's prerogative to offer his or her ideas is usurped due to a strong teacher's agenda. In Roberts's (2006, p. 425) words, "the student's intellectual heritage is being imposed," and it is left up to the learner to uncover what place his or her beliefs, biases, and attitudes hold in the discussion (if any exists). Posed within the reductionist restraints of this model, there is little room for any in-depth look at how student ideas fit into the picture presented by the instructor, or any self-examination of biases, beliefs, and attitudes, which is inherent within the critical thinking process and the subsequent transformative learning. Justified belief versus opinion is not addressed in these courses, as there is one "right answer," held by the teacher. 
With its focus on solving present problems, without questioning current standards, the process of linear thinking finds a place within the imposition teaching style, with an implementation focus. However, if students are given the opportunity to share their ideas of why certain practices are more sustainable than others and to evaluate them, the possibility for deeper learning also exists to some degree.

Definitions of sustainability and imposition teaching style. One of the most common approaches to teaching sustainability is with a curriculum emphasis on definitions of sustainability. The pedagogical process here is best described as information delivery of the derivation of definitions and their purposes. The unidirectional conversation in such courses is delivered from the instructor directly to the learner; only the instructor holds the key to the domain of knowledge. As in the implementation emphasis, the student's intellectual heritage is being imposed, and his or her prerogative to be part of the conversation is denied.

In a recent study that included sustainability pedagogy (Lozano, Ceulemans, \& Scarff Seatter, 2015), a one-hour lecture was followed by student participation in tutorial groupings. This does appear to have made a definite move in the direction proposed in this paper, even though this strategy does not completely override the "Sage on the Stage" lecture for the first hour of each class. It has been found that it is most desirable to "focus on the need to facilitate students in making sense of ideas and concepts immediately, rather than using the lecture as a place to gather ideas which later could be addressed (by someone else) in tutorials" (Tormey et al., 2008, p. 435, emphasis added).

Each of the three approaches to sustainability depicted in the table above is subject to the abandonment style of teaching (Roberts, 1996; Roberts \& Silva, 1968). As an example of an extreme relativist interpretation of constructivist theory, "abandonment" allows students' prior knowledge, ideas, and beliefs to reign supreme; indeed, these provide the source and framework for the process and outcomes of classroom topics (Scarff Seatter, 2003). Students in several studies (e.g., Hayes-Conroy \& Vanderbeck, 2005) have spoken of the comfort level found in HESD classes where their passionate and emotional responses-often ungrounded in reason-to sustainability work are supported and nurtured. Although an instructor who listens, cares for, and supports his or her students exhibits necessary educator qualities, there is little evidence that students are encouraged to make judgments based on evidence and critical reflection in abandonment-style classes. The abandonment style of teaching is in evidence when students arrive at class with a particular mindset that is reinforced and remains unchallenged.

\section{Interdependence of Curriculum, Pedagogy, and Transformative Learning}

Transformative learning refers to a change in the frame of reference, moving from a personal framework of individual ideas into one that references multiple views. Within this change comes decision making that is more enlightened and more likely to be based on sound reasoning. An understanding of sustainability, with its three-fold frame of referencethat is, the internal conflict among its components of societal, environmental, and economic sustenance-requires teaching that facilitates transformative learning. Effective HESD is only possible where transformative learning conditions exist. It follows that transformative learning can occur in other places and with other mentors (e.g., parents and community leaders), but within the university classroom an instructor can either stand in the way of (imposition style teaching) or facilitate (trialogue style teaching) transformative learning. 


\section{Conclusions}

Present and future HESD program instructors should be aware of the disparate approaches in emphases and teaching styles regarding sustainability, and their implications for student learning. The HESD curriculum and pedagogy table included within the discussion section on pedagogical teaching styles and sustainability emphases can be utilized as a starting point for further inquiry into the essential elements of effective pedagogy for sustainability in higher education.

Three persistent questions arise:

First, "Does formal education have the capacity to promote transformative learning within HESD?" The authors' answer is, "Yes, but only under conditions similar to those described above, where the student and his/her thoughts and beliefs are an integral component of the curriculum and pedagogy."

Second, "Is there really not any place for 'telling' in teaching?" The authors' answer is again, "Yes, of course. However, the telling must be engaging and support learners' active participation. Do not expect learning to occur when "telling" is the dominant pedagogical tool."

Third, "Could a 'critical trialogue' applied to any of the three approaches lead to transformative learning?" The authors could say that although the trialogue fits most naturally into the "Sustainability as Discourse" curriculum, and although the definitions and implementation courses are limited in opportunities for critical thinking and transformative learning, they can only be improved by such an approach.

In summary, there is a paradox within the higher education community of teaching and learning sustainability. HESD potentially supports and facilitates transformative learning-that is, within the topic itself is a sense of urgency whereby young scholars can examine their biases, beliefs, and values, be motivated to seek and assess that which is reasonable in forming new judgments, and construct new knowledge and understanding that serves them and others well for their future. This seldom happens.

The paradox lies in the vast dissimilarity between the potential challenge to students' critical and creative thinking processes, open-mindedness, and resultant transformative learning, within the inherently provocative and complex nature of sustainability work and the disengagement of the learner within much of HESD today. One can only conclude that there is a lack of sustenance within sustainability curricula and pedagogies in higher education, which tend to reinforce a reductionist agenda that negates the need for individual students to think, transform, and make sound judgments. Today's students need to be able to recognize the unsustainability of contemporary problem solving, cease searching for the "one right answer," and think instead in terms of good ideas and best solutions. The inarguable quotation below best describes the position of the authors of this paper:

Nobody has a single right vision of what a "good" lifestyle entails. Nobody yet knows how to best to sustain the earth's ecosystems for the benefits of ourselves, our children [...]. It is a myth to think that there is a single right vision or a best way to sustain the earth or what kind of earth should be sustained. (Wals \& Jickling, 2002, p. 223-224)

With this open-minded perspective on the challenge of solving the problems of sustainability, we can begin to think in terms of an open-minded, transformative approach 
in order to overcome the paradox of a powerful sustainability message framed within a powerless pedagogy.

\section{Acknowledgements}

The authors would like to acknowledge Dr. Rodrigo Lozano and Dr. Valérie Cappuyns for their valuable comments on this paper. Kim Ceulemans's postdoctoral fellowship at the Centre for Social and Sustainable Innovation, Gustavson School of Business, University of Victoria is funded by a donation from Goldcorp Inc.

\section{References}

Åke Bjørke, S. (2014). Transformative pedagogy. Retrieved from http://ufbutv.com/ e-learning/transformative-pedagogy

Alvarez, A., \& Rogers, J. (2006). Going "out there": learning about sustainability in place. International Journal of Sustainability in Higher Education, 7(2), 176-188.

Barth, M., Godemann, J., Rieckmann, M., \& Stoltenberg, U. (2007). Developing key competencies for sustainable development in higher education. International Journal of Sustainability in Higher Education, 8(4), 416-430.

Bennetts, C. (2003). The impact of transformational learning on individuals, families and communities. International Journal of Lifelong Education, 22(5), 457-480.

Bhaskar, R. (2009). Scientific realism and human emancipation. New York, NY: Routledge.

Bonwell, C. C., \& Eison, J. A. (1991). Active learning: Creating excitement in the classroom. ASHE-ERIC Higher Education Report No. 1. Washington, DC: The George Washington University, School of Education and Human Development.

Buckler, C., \& Creech, H. (2014). Shaping the future we want. United Nations Decade of Education for Sustainable Development (2005-2014). Final report. Decade of Education for Sustainable Development monitoring and evaluation. Paris, France: UNESCO.

Carew, A., \& Mitchell, C. (2008). Teaching sustainability as a contested concept: capitalizing on variation in engineering educators' conceptions of environmental, social and economic sustainability. Journal of Cleaner Production, 16, 105-115.

Case, R., \& Daniels, L. (2002). Introduction to the TC2 conception of critical thinking. Retrieved from http://tc2.ca/pdf/About\%20Critical\%20Thinking/Online\%2oArticles/ Understanding\%20Critical\%20Thinking/Introduction\%20to\%2othe\%20TC2\%20 Conception\%20w_\%20new\%20copyright.pdf

Ceulemans, K., \& De Prins, M. (2010). Teacher's manual and method for SD integration in curricula. Journal of Cleaner Production, 18(7), 645-651.

Cortese, A. (2003). The critical role of higher education in creating a sustainable future. Planning for Higher Education, 31(3), 15-22.

Cotton, D. (2006). Teaching controversial environmental issues: Neutrality and balance in the reality of the classroom. Education Research, 48(2), 223-241. 
Cranton, P. (1994). Understanding and promoting transformative learning: A guide for educators of adults. New York, NY: Doubleday.

Darier, E. (1996). Environmental governmentality: The case of Canada's green plan. Environmental Politics, 5(4), 585-606.

De Freitas, S., \& Oliver, M. (2006). How can exploratory learning with games and simulations within curriculum be most effectively evaluated? Computers \& Education, 46, 249-264.

Dunlap, R. E., Van Liere, K. D., Mertig, A. G., \& Jones, R. E. (2000). Measuring endorsement of the New Ecological Paradigm: A revised NEP scale. Journal of Social Issues, 56(3), 425-442.

Egan, K. (2012). What is curriculum? In S. Gibson (Ed.), Canadian curriculum studies: Trends, issues, and influences (pp. 29-37). Vancouver, BC: Pacific Educational Press.

Felder, R. M., Felder, G. N., \& Dietz, E J. (1998). A longitudinal study of engineering student performance and retention. V. Comparisons with traditionally-taught students. Journal of Engineering Education, 87(4), 469-480.

Ferreira, A. J. D., Lopes, M.A. R., \& Morais, J. P. F. (2006). Environmental management and audit schemes implementation as an educational tool for sustainability. Journal of Cleaner Production, 14(9-11), 973-982.

Fortuin, I. K. P. J., \& Bush, S. R. (2010). Educating students to cross boundaries between disciplines and cultures and between theory and practice. International Journal of Sustainability in Higher Education, 11(1), 19-35.

Grand Challenges Canada (2016). Grand Challenges Canada [Home page]. Retrieved from http://www.grandchallenges.ca

Greene, M. (1973). Teacher as stranger: Educational philosophy for the modern age. Belmont, CA: Wadsworth Publishing.

Greene, M. (2001). Variations on a blue guitar: The Lincoln Center Institute lectures on aesthetic education. New York, NY: Teachers College Press.

Hanson, N. (1958). Patterns of discovery: An inquiry into the conceptual foundations of science. New York, NY: Cambridge University Press.

Hauenstein, A. (1998). A conceptual framework for educational objectives: A holistic approach to traditional taxonomies. Lanham, MD: University Press of America.

Hayes-Conroy, J., \& Vanderbeck, R. (2005). Ecological identity work in higher education: Theoretical perspectives and a case study. Ethics, Place \& Environment, 8(3), 309-329.

Hoogeveen P., \& Winkels J. (1996). Het didactische werkvormenboek. Variatie en differentiatie in de praktijk. [Teaching methods book. Variation and differentiation in practice.] Assen, The Netherlands: Van Gorcum.

Huckle, J. (2006). Education for sustainability: Some guidelines for curriculum. Retrieved from http://john.huckle.org.uk/publications_downloads.jsp

James, M., \& Card, K. (2012). Factors contributing to institutions achieving environmental sustainability. InternationalJournal of Sustainability in Higher Education, 13(2), 166-176. 
Justice, C., Rice, J., Roy, D., Hudspith, B., \& Jenkins, H. (2009). Inquiry based learning in higher education: Administrators' perspectives on integrating inquiry pedagogy into the curriculum. Higher Education, 58(6), 841-855.

Juárez-Nájera, M., Dieleman, H., \& Turpin-Marion, S. (2006). Sustainability in Mexican higher education: Towards a new academic and professional culture. Journal of Cleaner Production, 14(9-11), 1028-1038.

Kowalewski, D. (2002). Teaching deep ecology: A student assessment. The Journal of Environmental Education, 33(4), 20-27.

Leal Filho, W., MacDermot, F., \& Padgam, J. (1996). Implementing sustainable development at university level: A manual of good practice. Bradford, UK: Centre on Environmental Education.

Levkoe, C., Brail, S., \& Daniere, A. (2014). Engaged pedagogy and transformative learning in graduate education: A service-learning case study. Canadian Journal of Higher Education, 44(3), 68-85.

Lourdel, N., Martin, J., \& Bererd, O. (2006). Overcoming obstacles to understanding sustainable development-An approach based on personal experiences. Paper presented at the Engineering Education for Sustainable Development (EESD) 2006 Conference, Lyon, France.

Lozano, R. (2006). Incorporation and institutionalization of SD into universities: Breaking through barriers to change. Journal of Cleaner Production, 14, 787-796.

Lozano, R. (2014). Creativity and organizational learning as means to foster sustainability. Sustainable Development, 22(3), 205-216.

Lozano, R., Ceulemans, K., \& Scarff Seatter, C. (2015). Teaching organizational change management for sustainability: Designing and delivering a course at the University of Leeds to better prepare future sustainability change agents. Journal of Cleaner Production, 106, 205-215.

Luke, T. (1999). Environmentality as green governmentality. In E. Darier (Ed.), Discourses of the environment (pp. 121-151). Oxford, UK: Blackwell.

Mezirow, J. (1990). How critical reflection triggers transformative learning. In J. Mezirow and Associates, Fostering critical reflection in adulthood (pp. 1-20), San Francisco, CA: Jossey Bass.

Mezirow, J. (1997). Transformative learning: Theory to practice. New Directions for Adult and Continuing Education, 74, 5-12.

Mogensen, F. (1997). Critical thinking: A central element in developing action competence in health and environmental education. Health Education Research, 12(4), 429-436.

Moore, J. (2005). Seven recommendations for creating sustainability education at the university level: A guide for change agents. International Journal of Sustainability in Higher Education, 6(4), 326-339.

Morris, M. (2002). Ecological consciousness and curriculum. Journal of Curriculum Studies, 34(5), 571-578. 
My Sustainable Canada. (2016). My Sustainable Canada [Home page]. Retrieved from http://www.mysustainablecanada.org

Myers, E. M., \& Beringer, A. (2010). Sustainability in higher education: Psychological research for effective pedagogy. Canadian Journal of Higher Education, 4O(2), 51-77.

Nie, Y., \& Lau, S. (2010). Differential relations of constructivist and didactic instruction to students' cognition, motivation and achievement. Learning \& Instruction, 2O(5), 411-423.

Orr, D. (1992). Ecological literacy: Education and the transition to a postmodern world. New York, NY: SUNY.

Orr, A. M., \& Olson, M. (2007). Transforming narrative encounters. Canadian Journal of Education, 30(3), 819-838.

Oxford University Press (2009). Oxford dictionary of current English (4th ed.). Oxford, UK: Oxford University Press.

Ozkal, K., Tekkaya, C., Cakiroglu, J., \& Sungur, S. (2009). A conceptual model of relationships among constructivist learning environment perceptions, epistemological beliefs, and learning approaches. Learning and Individual Differences, 19(1), 71-79.

Phillips, D. (1995). The good, the bad, and the ugly: The many faces of constructivism. Educational Researcher, 24(7), 5-12.

Prosser, M., \& Trigwell, K. (1999). Understanding learning and teaching: The experiences of higher education. Buckingham, UK: Open University Press.

Rathzel, N., \& Uzzell, D. (2009). Transformative environmental education: A collective rehearsal for reality. Environmental Education Research, 15(3), 263-277.

Roberts, D. (1996). Epistemic authority for teacher knowledge: The potential role of teacher communities: A response to Robert Orton. Curriculum Inquiry, 26(4), 417-431.

Roberts, D., \& Silva, D. (1968). Curriculum design, teaching styles and consequences for students. Samplings, 1(4), 16-28.

Scarff Seatter, C. (1998). An analysis of the concept of teaching in elementary school science education (Unpublished doctoral dissertation). Simon Fraser University, Burnaby, BC.

Scarff Seatter, C. (2003). Constructivist science teaching: Intellectual and strategic teaching acts. Interchange, 34(1) 63-87.

Scarff Seatter, C. (2011). A critical stand of my own: Complementarity of responsible environmental sustainability education and quality thinking. Journal of Educational Thought, 45(1), 21-58.

Schelfhout, W., Dochy, F., Janssens, S., Struyven, K., Gielen, S., \& Sierens, E. (2006). Educating for learning-focused teaching in teacher training: The need to link learning content with practice experiences within an inductive approach. Teaching and Teacher Education, 22(7), 874-897.

Segalàs, J., Ferrer-Balas, D., \& Mulder, K. (2010). What do engineering students learn in sustainability courses? The effect of the pedagogical approach. Journal of Cleaner Production, 18(3), 275-284. 
Segalàs, J., Mulder, K., \& Ferrer-Balas, D. (2012). What do EESD "experts" think sustainability is? Which pedagogy is suitable to learn it? International Journal of Sustainability in Higher Education, 13(3), 293-304.

Shor, L. (1993). Education is politics: Paulo Freire's critical pedagogy. In P. McLaren, \& P. Leonard (Eds.), Paulo Freire: A critical encounter (pp. 25-35). London, UK: Routledge.

Short,P. (2010). Responsible environmental action: Its role and status in environmental education and environmental quality. The Journal of Environmental Education, 41(1), 7-21.

Singer, F., \& Moscovici, H. (2008). Teaching and learning cycles in a constructivist approach to instruction. Teaching \& Teacher Education, 24(6), 1613-1634.

Sipos, Y., Battisti, B., \& Grimm, K. (2008). Achieving transformative sustainability learning: Engaging head, hands and heart. International Journal of Sustainability in Higher Education, 9(1), 68-86.

Sprain, S., \& Timpson, W. (2012). Pedagogy for sustainability science: Case-based approaches for interdisciplinary instruction. Environmental Communication: A Journal of Nature and Culture, 6(4), 532-550.

Steiner, G., \& Posch, A. (2006). Higher education for sustainability by means of trans-disciplinary case studies: An innovative approach for solving complex, real-world problems. Journal of Cleaner Production, 14(9-11), 877-890.

Sterling, S. (2001). Sustainable education: Re-visioning learning and change. Totnes, UK: Green Books, for the Schumacher Society.

Sullivan, R. N., \& McIntosh, N. (1996). Delivering effective lectures. Paper \#5. Washington, DC: U.S. Agency for International Development.

Svanström, M., Lozano-Garcia, F., \& Rowe, D. (2008). Learning outcomes for sustainable development in higher education. International Journal of Sustainability in Higher Education, 9(3), 339-351.

Taylor, P., Fraser, B., \& Fisher, D. (1997). Monitoring constructivist classroom learning environments. International Journal of Educational Research, 27(4), 293-302.

Tenenbaum, G., Naidu, S., Jegede, O., \& Austin, J. (2001). Constructivist pedagogy in conventional on-campus and distance learning practice: An exploratory investigation. Learning and Instruction, 11(2), 87-111.

Thomas, I. (2004). Sustainability in tertiary curricula: What is stopping it happening? International Journal of Sustainability in Higher Education, 5(1), 33-47.

Tinto, V. (1997). Classrooms as communities: Exploring the educational character of student persistence. The Journal of Higher Education, 68(6), 599-623.

Tormey, R., Liddy, M., Maguire, H., \& McCloat, A. (2008). Working in the action/ research nexus for education for sustainable development: Two case studies from Ireland. International Journal of Sustainability in Higher Education, 9(4), 428-440. 
Tynjala, P. (1999). Towards expert knowledge? A comparison between a constructivist and a traditional learning environment in the university. International Journal of Educational Research, 31, 357-442.

UNESCO. (2006). Framework for the UN DESD International Implementation Scheme. ED/DESD/2006. Retrieved from http://unesdoc.unesco.org/images/o014/ 001486/14865oE.pdf

UNESCO. (2009). UNESCO World Conference on Education for Sustainable Development. Retrieved from http://unesdoc.unesco.org/images/o018/o01887/188799e. pdf

UNESCO. (2012). Education for sustainable development sourcebook. Education for sustainable development in action. Learning and training tools. N4-2012, 51. Paris, France: Author.

UNESCO. (2014). UNESCO roadmap for implementing the Global Action Programme on Education for Sustainable Development. Paris, France: Author.

Velazquez, L., Munguia, N., Zavala, A., \& Esquer, J. (2002). Sustainable good practices in the University of Sonora, Mexico. Global University Network for Innovation. Retrieved from http://www.guninetwork.org/articles/sustainable-good-practices-university-sonoramexico

Wackernagel, M., \& Rees, W. (1996). Our ecological footprint: Reducing human impact on the Earth. Gabriola Island, BC: New Society Publishers.

Wals, A., \& Blaze Corcoran, P. (2006). Sustainability as an outcome of transformative learning. Education for Sustainable Development in Action, Technical Paper No. 3. In J. Holmberg \& B. Samuelsson (Eds.), Drivers and barriers for implementing sustainable development in higher education. Paris, France: UNESCO.

Wals, A., \& Jickling, B. (2002). "Sustainability" in higher education: From doublethink and newspeak to critical thinking and meaningful learning. International Journal of Sustainability in Higher Education, 3(3), 221-232.

Wiggins, G., \& McTighe, J. (2005). Understanding by design (expanded 2nd ed.). Alexandria, VA: Association for Supervision and Curriculum Development.

Wooltorton, S. (2002). Education for sustainability: A background paper prepared for the State Sustainability Strategy. Perth, Australia: Department of the Premier and Cabinet.

\section{Contact Information}

Carol Scarff Seatter

Faculty of Education

University of British Columbia

carol.scarff@ubc.ca

Carol Scarff Seatter is currently an associate professor at the University of British Columbia, where she serves as Chair of Interdisciplinary Graduate Studies in Sustainability 
and as a researcher in education for sustainability in higher education, school-mediated "green" strategies for educators, and developing a critical consciousness in sustainability.

Kim Ceulemans is a postdoctoral fellow of the Centre for Social and Sustainable Innovation at Gustavson School of Business, University of Victoria. Kim's research is focused on how higher education institutions integrate (aspects of) sustainability in their curricula, research, outreach activities, and daily operations. She earned her doctorate at KU Leuven University's Faculty of Economics and Business, in Belgium, by studying the topic of sustainability reporting in higher education. 